\title{
PERANAN PENDIDIKAN FORMAL DALAM PROSES PEMBUDAYAAN
}

\author{
Oleh: Juanda*
}

\begin{abstract}
This article deals the role of formal education in the process of enculturation, including six aspects: education and enculturation, educational policy in Indonesia, educational aspects as cultural phenomena, the functions of culture in education, the role of formal education in the process of enculturation, and the process of enculturation through formal education. The policy of equal right for education is designed to give equal opportunity to all people to get education without discrimination to any ethnic group. Education is an endeavour of developing the community culture to be a modern society, developed and harmonious based on the shared cultural values. Enculturation process is an attempt to guide someone's attitude and behaviour based on science and skill.
\end{abstract}

KEYWORDS: Pendidikan formal, pembudayaan, dan kebijakan pendidikan.

PENCIPTA dan pendukung budaya adalah manusia. Manusia lahir tanpa kekosongan budaya, yaitu manusia yang dilahirkan di dunia ini dalam keluarga atau masyarakat tempat dilahirkan, masyarakat tersebut telah menganut budaya tertentu. Anggota keluarga dan masyarakat tempat seseorang dilahirkan tersebut telah menganut budaya. Budaya yang dianut diwariskan dari generasi ke generasi melalui proses pembelajaran dalam dunia pendidikan formal dan nonformal. Pendidikan merupakan gejala kebudayaan. Pendidikan hanya dapat dilakukan oleh mahluk yang berbudaya dan yang menghasilkan nilai kebudayaan adalah manusia. Asasasas pendidikan selalu harus berdasarkan pada budaya.

Proses pendidikan merupakan upaya sadar manusia yang tidak pernah ada hentinya. Sebab bilamana manusia berhenti melakukan pendidikan, sulit dibayangkan apa yang akan terjadi pada sistem peradaban dan budaya manusia. Oleh karena itu, pemerintah maupun masyarakat berupaya untuk melakukan pendidikan dengan standar kualitas yang

*Doktor dalam bidang Ilmu Pendidikan Bahasa pada Program Pascasarjana Universitas Negeri Jakarta ini adalah dosen Fakultas Sastra dan Seni Universitas Negeri Makassar. 
dinginkan untuk memberdayakan manusia. Sistem pendidikan yang dibangun harus disesuaikan dengan tuntutan zamannya agar pedidikan dapat menghasilkan outcome yang relevan dengan tuntutan zaman. Di sinilah peranan pemerintah sebagai pihak yang memiliki kewenangan dalam menentukan kebijakan pendidikan di Indonesia. Dalam hal ini tentu saja kebijakan tersebut harus selalu memperhatikan nilai-nilai budaya yang dipegang teguh oleh pendukung budaya tempat pendidikan diselenggarakan.

Kebudayaan diwariskan dari generasi ke generasi dengan cara belajar. Menurut Sultan Takdir Alisjahbana kebudayaan adalah keseluruhan gagasan dan karya manusia yang harus dibiasakannya dengan belajar beserta keseluruhan dari hasil budi pekertinya. Tujuan Pendidikan yang digariskan dalam UU No. 20/2003 pasal 3 pada akhirnya adalah terbentuknya kemampuan dan watak seperti juga yang dirumuskan oleh UNESCO, to muold the character and mind of young generation. Kepribadian hanya dapat dibentuk melalui interaksi personal, proses meniru, proses pemahaman, toleransi dan berbagai soft skill hanya dapat dikembangkan melalui apa yang disebut oleh Rogers ${ }^{1}$ dengan helping relationship sebagai pembuka jalan proses becoming. Arah, tujuan, atau sasaran yag diperhatikan dan dibina serta dijadikan pedoman dalam pelaksanaan segala aktivitas yang bersifat pendidikan harus memperhatikan aspek-aspek pendidikan sebagai gejala kebudayaan.

Sumber daya manusia yang berpendidikan akan menjadi modal utama pembangunan nasional, terutama untuk perkembangan ekonomi. Semakin banyak orang yang berpendidikan maka semakin mudah bagi suatu negara untuk membangun bangsanya. Hal ini terjadi karena dikuasainya keterampilan, ilmu pengetahuan dan teknologi oleh sumber daya manusianya sehingga pemerintah lebih mudah dalam menggerakkan pembangunan nasional. Bangsa yang maju di dunia ini adalah bangsa yang mempertahankan kekhasannya. Sebagaimana kita ketahui bahwa salah satu unsur kebudayaan adalah bahasa. Negara yang maju di dunia ini adalah negara yang memprioritaskan penggunaan bahasa nasionalnya sebagai bahasa pengantar dalam dunia pendidikan sehingga peserta didik lebih leluasa mengembangkan kreativitasnya. Mereka menuangkan pikirannya, gagasan-gagasannya dalam bentuk konsep dengan keyakinan yang pada akhirnya menghasilkan suatu inovasi berupa penemuan. Peranan fungsi budaya dalam pendidikan sangat penting.

Pendidikan formal telah diselenggarakan di Indonesia yang tentu saja harus memperhatikan aspek-aspek budaya dalam penyajian materi pada setiap mata pelajaran. Keseluruhan mata pelajaran dalam pengajaran 
seharusnya disesuaikan dengan budaya Indonesia. Penemuan atau inovasi yang muncul hanya dapat terwujud bilamana menggali dari potensi yang ada atau mengutamakan kekhasan, ciri khas atau budaya setempat. Oleh karena itu, proses pembudayaan pada anak didik atau siswa perlu dimaksimalkan terutama dengan melalui pendidikan formal.

\section{PERNYATAAN MASALAH}

Berdasarkan latar belakang masalah di atas, muncul masalah yang dapat dirumuskan sebagai berikut:

1. Apakah pendidikan dan pembudayaan itu?

2. Bagaimanakah kebijakan pendidikan di Indonesia?

3. Aspek-aspek apa saja dalam pendidikan sebagai gejala kebudayaan?

4. Bagaimanakah fungsi budaya dalam pendidikan?

5. Apa peranan pendidikan formal dalam proses pembudayaan?

6. Bagaimana proses pembudayaan melalui pendikan formal?

\section{PEMBAHASAN}

\section{Pendidikan dan Pembudayaan}

Menurut bahasa Yunani pendidikan berasal dari kata pedagogi yaitu kata paid artinya anak sedangkan agogos artinya membimbing sehingga pedagogi dapat diartikan sebagai ilmu dan seni mengajar anak. Menurut UU No. 20 tahun 2003 tentang sistem pendidikan nasional pendidikan adalah usaha sadar dan terencana untuk mewujudkan suasana belajar dan proses pembelajaran agar peserta didik secara aktif mengembangkan potensi dirinya untuk memiliki kekuatan spritual keagamaan dan pengendalian diri. Kepribadian, kecerdasan, akhlak mulia, serta keterampilan yang diperlukan dirinya, masyarakat, bangsa, dan negara.

Dari pernyataan di atas dapat disimpulkan bahwa pendidikan adalah usaha sadar dan terencana untuk mewujudkan suasana belajar dan proses pembelajaran atau pelatihan agar peserta didik secara aktif dapat mengembangkan potensi dirinya supaya memiliki kekuatan spritual keagamaan, emosional, pengendalian diri, kepribadian, kecerdasan, akhlak mulia, serta keterampilan yang diperlukan dirinya dan masyarakat. ${ }^{2}$ Menurut R. Linton kebudayaan dapat dipandang sebagai konfigurasi tingkah laku yang dipelajari dan hasil tingkah laku yang dipelajari, unsur pembentuknya didukung dan diteruskan oleh anggota masyarakat lainnya. Jadi, pembudayaan harus melalui pendidikan apakah itu pendidikan melalui jalur formal atau nonformal.

Suatu pandangan bahwa budaya adalah sesuatu yang dipelajari, diteruskan, disampaikan dari satu generasi ke generasi berikutnya. Selan- 
jutnya tindakan manusia selalu dalam bentuk interaksi tatap muka dan tentu saja menggunakan bahasa sebagai sarana komuniaksi. Dalam pandangan ini budaya dimaksudkan menjelaskan bagaimana anak perkembangannya mengikuti pola-pola budaya pada orang yang memeliharanya. Anak akan tumbuh menjadi anggota budaya dari budaya yang dianut oleh orang tuanya. ${ }^{3}$

Perolehan kebudayaan oleh manusia terjadi melalui proses yang disebut pendidikan. Dalam pengertian ini pendidikan adalah jalur mewariskan dan mewarisi kebudayaan. Akan tetapi pewarisan melulu tidaklah cukup sebagai tujuan pendidikan dengan upaya pendidikan, kita perlu juga membuat anak-anak didik itu kreatif dan berinisiatif. Dalam hal ini tidak boleh lepas dari koridor pembudayaan.

Dalam antropologi budaya dipelajari dan sebagai bagian karakteristik pola perilaku dalam kelompoknya. Budaya yang kita miliki telah dipelajari dari keluarga dan anggota lain dalam masyarakat yang seperti halnya bentuk materi yang berupa buku dan program televisi. Kita tidak dilahirkan dengan kekosongan budaya tetapi dengan kemampuan memperoleh budaya itu dengan pengamatan, peniruan, dan coba dan mencoba.

Pendidikan dan pembudayaan harus dimulai sejak dini pada anakanak. Dalam hal ini bahasa yang sifatnya sopan dan santun pada anak sangat penting. Kita tidak boleh lupa pada pendidikan bahasa anak pada saat balita. Masih banyak orang tua yang masih mau bertengkar, mengeluarkan kata-kata kotor dan pedas, saling umpat di hadapan anaknya yang sedang tumbuh kembang. Dapat dibayangkan begitu banyak anak-anak sekarang yang walaupun baru berumur lima tahun bahkan di bawanya sudah bisa mengeluarkan kata-kata yang tidak pantas. Itulah sebabnya mulai sekarang kita harus menyadari apa yang pantas dan yang tidak pantas diucapkan di depan anak-anak. Kita seharusnya menggunakan kata sopan, santun dan yang baik menurut moral setiap saat berhadapan dengan anak. Hal ini merupakan salah satu proses pendidikan dan pembudayaan dalam penggunaan bahasa.

\section{Kebijakan Pendidikan di Indonesia}

Indonesia telah memiliki sebuah sistem pendidikan yang telah dikokohkan dengan UU No. 20 tahun 2003. Pembangunan di Indonesia sekurang-kurangnya menggunakan empat strategi dasar: 1. Pemerataan kesempatan memperoleh pendidikan; 2. Relevansi pendidikan; 3. Peningkatan kualitas pendidikan; dan 4. efisiensi pendidikan. Secara umum starategi itu dapat dibagi menjadi dua dimensi yakni peningkatan mutu dan pemerataan pendidikan. Pembangunan peningkatan mutu diharapkan 
dapat meningkatkan efisiensi, efektivitas, dan produktivitas pendidikan. Sedangkan kebijakan pemerataan pendidikan diharapkan dapat memberikan kesempatan yang sama dalam memperoleh pendidikan bagi semua usia sekolah. ${ }^{4}$ Selanjutnya Sanaky ${ }^{5}$ mengemukakan bahwa untuk menjamin kesempatan memperoleh pendidian yang merata di semua kelompok stara dan wilayah tanah air sesuai dengan kebutuhan dan tingkat perkembangannya perlu strategi dan kebijakan pendidikan, yaitu: 1. Menyelenggarakan pendidikan yang relevan dan bermutu sesuai dengan kebutuhan masyarakat Indonesia dalam menghadapi tantangan global; 2 menyelenggarakan pendidikan yang dapat dipertanggung-jawabkan kepada masyarakat sebagai pemilik sumber daya dan dana serta pengguna hasil pendidikan; 3. Menyelenggarakan proses pendidikan yang demokratis secara profesional sehingga tidak mengorbankan mutu pendidikan; 4. Meningkatkan efisiensi internal dan eksternal pada semua jalur, jenjang, dan jenis pendidikan, 5. Memberi peluang yang luas dan meningkatkan kemampuan masyarakat sehingga terjadi diversifikasi program pendidikan sesuai dengan sifat multikultural bangsa Indonesia; 6 . Secara bertahap megurangi peran pemerintah menuju ke peran fasilitator dalam implemetasi sistem pendidikan; 7. Merampingkan birokrasi pendidikan sehingga lebih fleksibel untuk menentukan atau melakukan penyesuaian terhadap dinamika perkembangan masyarakat dalam lingkungan global.

Proses menuju perubahan sistem pendidikan nasional banyak menuai kendala serius, apalagi membicarakan konteks pendidikan nasional sebagai bagian dari pergumulan ideologi dan politik penguasa. Problem-problem yang dihadapi berkaitan dengan kebijakan-kebijaan yang sangat strategis. Maka dalam konteks kebijakan pendidikan nasional menurut Suyanto 6 banyak pakar dan praktisi pendidikan mengkritisi pemerintah, dianggap tidak memiliki komitmen yang kuat untuk membenahi sistem pendidikan nasional. Kebijakan sistem pendidikan kita kurang menggambarkan rumusan-rumusan permasalahan dan prioritas yang ingin dicapai dalam jangka waktu tertentu. Hal ini terutama berkaitan dengan anggaran pendidikan nasional yang semestinya mengalokasikan dana APBN dan APBD sebesar 20\% (Pasal 31 ayat 4 UUD amandemen keempat). Sampai sekarang kebijakan strategi belum dapat diwujudkan sepenuhnya.

\section{Aspek-Aspek Pendidikan Sebagai Gejala Kebudayaan}

Aspek-aspek pendidikan adalah arah, tujuan atau sasaran yang diperhatikan dan dibina serta dijadikan pedoman dalam pelaksanaan segala aktivitas yang bersifat pendidikan, aspek-aspek tersebut menurut Harahap, 7 adalah: 
a. Pendidikan adalah pembinaan tingkah laku perbuatan

Pendidikan merupakan proses pembinaan tingkah laku perbuatan agar anak belajar berpikir, berperasaan dan bertindak lebih sempurna dan baik daripada sebelumnya. Untuk tujuan tersebut maka pendidikan diarahkan pada seluruh aspek pribadi meliputi jasmani, mental kerohanian dan moral. Dalam hal ini akan tumbuh kesadaran pribadi dan bertanggung jawab akibat tingkat perbutannya.

b. Pendidikan adalah pendidikan diri pribadi

Lembaga pendidikan bertujuan mengembangkan diri dan selalu menggunakan daya kemampuan inisiatif dan aktivitasnya sesuai kata hatinya sehingga anak berkesempatan untuk belajar memikul tanggung jawab bagi kelangsungan pendidikan dan perkembangan pribadinya. Hal ini sesuai dengan pernyataan Tagore bahwa pendidikan sebenarnya pendidikan diri sendiri atau diri pribadi (self education).

c. Pendidikan diperankan di berbagai pusat lembaga

Tugas pendidikan adalah tugas yang harus dilaksanakan oleh lembaga atau badan pendidikan yang diakui dan diberi hak hidup serta dilindungi undang-undang. Dengan demikian, di samping lembaga pendidikan sekolah (sebagai perantara, pemersatu serta mempertinggi usaha pendidikan maka keluarga masyarakat juga menerima tugas kewajiban untuk mendidik manusia yang menjadi anggotanya.

d. Pendidikan diarahkan kepada keseluruhan aspek kebudayaan dan kepribadian

Pendidik dan lembaga pendidikan harus mengakui kepribadian dan menggalang adanya kesatuan segala aspek kebudayaan. Di sini manusia membutuhkan latihan dalam menggunakan kecerdasannya dan saling pengertian. Aspek-aspek kehidupan telah dirumuskan oleh Springer ${ }^{8}$ sebagai aspek intelek yang menghasilkan manusia teoretis, sosial, pengabdi, estetis, seni, politik, manusia berkuasa, dan ekonomi manusia serta ditambahkan di dalam aspek keluarga menjadikan manusia cinta kasih.

e. Pendidikan berlangsung sepanjang hidup

Menurut Langeveld kewibawaan penting dalam pendidikan sehingga proses pendidikan dibatasi pada proses pendidikan mulai dari anak mengerti dan mengakui kewibawaan sampai anak tunduk dan kewibawaannya sendiri yang bersumber dari kata hatinya.

f. Pendidikan adalah persiapan penyesuaian yang intellegent terhadap perubahan sosial. Sifat pendidikan reflektif dan progresif harus meneruskan nilai kebudayaan dan mengantarkan anak didik pada alam kedewasaan serta membimbing ke arah kerja membangun masa depan. Jadi, pendidik harus mengembangkan kesadaran bertangung jawab dan turut serta dalam masyarakat. 
g. Pendidik harus mengabdi kepada seluruh massa rakyat

Menurut sejarah perkembangannya, pendidikan mengalami dua macam perkembangan, yaitu: 1. Pendidikan sebagai pengabdi kelas/golongan masyarakat diperuntukkan untuk kepentingan sebagian kecil masyarakat misalnya kolonial Belanda dan; 2. Pengabdi massa/segala lapisan masyarakat, diperuntukkan untuk demokrasi masyarakat tanpa perbedaan kelas.

h. Pendidikan harus diarahkan ke pembinaan cita-cita hidup yang luhur Bila pendidikan dimasukkan ke dalam tingkah laku perbuatan manusia maka pendidikan harus menyesuaikan diri dengan tujuan hidup manusia, selanjutnya tujuan hidup tersebut ditentukan oleh filsafat hidup yang dianut seseorang. Tujuan pendidikan manusia harus bersumber pada filsafat hidup individu tertentu.

i. Pendidikan jiwa nasionalisme seimbang dengan jiwa internasionalisme Pendidikan adalah pembinaan jiwa nasionalisme yang sehat dan wajar, tidak menjurus chauvinisme atau internasionalisme yang melenyapkan jiwa nasionalisme. Adanya masalah dan perbedaan dan paham-paham tersebut disebabkan oleh tiga hal, yaitu: tetap adanya perang, adanya efek relatif kebanggaan bangsa tertentu, namun kesengaraan bagi bangsa lainnya dan rasa kebersamaan pada bangsa-bangsa yang tertindas.

Pendidikan bertujuan mengusahakan perdamaian dan kesejahteraan manusianya. Untuk usaha-usaha yang mengarah ke sana adalah pembinaan jiwa yang saling kerja sama antar bangsa penghilangan nasionalisme yang sempit, peniadaan doktrin superioritas dan imperioritas ras, pengembangan sikap positif atas kerja sama, pembinaan politik luar negeri dalam prinsip konsultasi dan kooperatif, peningkatan taraf mental pendidikan manusia serta pembinaan penghormatan dan hidup yang berasaskan demokrasi individu, masyarakat dan antara bangsa. Hasil pembinaan di atas akan menimbulkan tiga kemungkinan: 1). Komunisme internasional, dengan bentuk terpimpin oleh negara super diikuti negara satelit; 2). Organisasi internasional, dengan peniadaan negara super, tata kehidupan berlandaskan demokrasi; 3). Kerja sama regional, bentuk kerja sama dalam wilayah dengan tujuan tertentu.

j. Pendidikan agama merupakan unsur mutlak dalam pembinaan karakteristik dan bangsa

Hal ini didasarkan atas pandangan bahwa agama merupakan unsur mutlak dan sumber dari kebudayaan. Pendidikan agama agar tidak diarahkan pada intelektualistis verbalistis sehingga menjadikan pendidikan agama sebagian dasar tata kehidupan manusia, pribadi, di sekolah maupun masyarakat. 
Pendidian agama tidak sama dengan etik, namun pendidikan pekerti tidak dapat dilepas dari agama sehingga dapat dikatakan kesusilaan yang diagamakan sehingga dihasilkan manusia berbudi luhur, sehat berpikiran bebas, pengalaman, pengetahuan luas dan berjiwa ikhlas.

\section{Fungsi Budaya Dalam Pendidikan}

Fungsi budaya merujuk pada sumbangan pendidikan pada peralihan dan perkembangan budaya pada tingkatan sosial yang berbeda. Pada tingkat individual pendidikan membantu siswa untuk mengembangkan kreativitasnya, kesadaran estetis serta untuk bersosialiasi dengan normanorma, nilai-nilai, dan keyakinan sosial yang baik. Orang yang berpendidikan diharapkan lebih mampu menghargai atau menghormati perbedaan dan pluralitas budaya sehingga memiliki sikap yang lebih terbuka terhadap keanekaragaman budaya. Dengan demikian, semakin banyak orang yang berpendidikan diharapkan akan lebih mudah terjadinya akulturasi budaya yang selanjutnya akan terjadi integrasi budaya nasional atau regional.

Professor Kinosita menyarankan bahwa yang diperlukan di Indonesia adalah pendidikan dasar dan bukan pendidikan yang canggih. Proses pendidikan pada pendidikan dasar setidaknya bertumpu pada empat pilar, yaitu: lerning to know, learning to do, learning to be, dan learning live together yang dapat dicapai melalui delapan kompetensi dasar, yaitu: membaca, menulis, mendengar, berbicara, menghitung, meneliti, menghafal, dan menghayal. ${ }^{9}$ Meskipun Indonesia terkeropos oleh arus global, pada dasarnya kita juga tidak ingin anak-anak kelak tercabut dari akar budayanya dalam situasi global tersebut. ${ }^{10}$ Pendidikan membantu siswa mengembangkan dirinya secara psikologis, sosial, fisik, dan membantu siswa mengembangkan potensinya semaksimal mungkin,11 sehingga mampu survive di tengah pergulatan global.

\section{Peranan Pendidikan Formal dalam Proses Pembudayaan (Enkulturasi)}

Pendidikan bertujuan membentuk agar manusia dapat menunjukkan perilakunya sebagai mahluk yang berbudaya yang mampu bersosialisasi dalam masyarakatnya dan menyesuaikan diri dengan lingkungannya dalam upaya mempertahankan kelangsungan hidup, baik secara pribadi, kelompok, maupun masyarakat secara keseluruhan. Sekolah atau pendidikan formal adalah salah satu sarana atau media dari proses pembudayaan media lainnya (keluarga dan institusi lainnya yang ada dalam masyarakat). Dalam konteks inilah pendidikan disebut sebagai proses untuk memanusiakan manusia (Dick Hartoko). Sejalan dengan itu kalangan antropolog 
dan ilmuwan sosial lainnya melihat bahwa pendidikan merupakan upaya untuk membudayakan dan men-sosialisasikan manusia sebagaimana yang kita kenal dengan enkulturasi, pembudayaan dan sosialisasi, proses membentuk kepribadian dan perilaku seseorang anak menjadi anggota masyarakat sehingga anak tersebut diakui keberadaannya oleh masyarakat yang bersangkutan. Budaya cocok pada anggota etnik kelompok yang kita punyai. Kita biasa menyebut identitas budaya. ${ }^{12}$

Daoed Joesoef memandang pendidikan sebagai bagian dari kebudayaan karena pendidikan adalah upaya memberikan pengetahuan dasar sebagai bekal hidup. Pengetahuan dasar sebagai bekal hidup yang dimaksudkan di sini adalah kebudayaan. Dikatakan demikian karena kehidupan adalah keseluruhan dari keadaan diri kita, totalitas dari apa yang kita lakukan sebagai manusia, yaitu sikap, usaha, dan kerja yang harus dilakukan oleh setiap orang, menetapkan suatu pendirian dalam tatanan kehidupan bermasyarakat yang menjadi ciri kehidupan manusia sebagai mahluk biososial.

Pendidikan adalah upaya menanamkan sikap dan keterampilan pada anggota masyarakat agar mereka kelak mampu memainkan peranan sesuai dengan kedudukan dan peran sosial masing-masing dalam masyarakat. Secara tidak langsung pola ini menjadi proses melestarikan suatu kebudayaan. Sejalan dengan ini Bertran Russel ${ }^{13}$ mengatakan pendidikan sebagai tatanan sosial kehidupan bermasyarakat yang berbudaya. Melalui pendidikan kita bisa membentuk suatu tatanam kehidupan bermasyarakat yang maju, modern, tenteram, dan damai berdasarkan nilai-nilai dan norma budaya.

Luaran pendidikan formal diharapkan memiliki sikap positif yang diwujudkan dalam bentuk perilaku yang religius, cekatan, terampil, dapat membedakan mana yang baik dan mana yang buruk, mana yang salah dan yang benar, menghargai semua hal yang menjadi bahagian kehidupan di alam ini termasuk segala bentuk perbedaan di antara sesama manusia. Memiliki kemampuan untuk mengambil keputusan yang tepat pada saat yang cepat serta mampu mengembangkan potensi diri dalam upaya meningkatkan kualitas pribadi, keluarga, kelompok, agama, bangsa, dan negara. Semua ini merupakan unsur pokok dalam proses pembentukan masyarakat yang sejahtera, survive, adil, makmur, dan penuh kedamaian.

Dalam mewujudkan hal ini para penyelengara pendidikan harus yakin bahwa program dan proses pembelajaran dapat menggiring siswa agar mampu mengunakan terhadap segala yang dimilikinya atau yang diperoleh selama proses belajar. Sehingga bermanfaat dalam kehidupan selanjutnya baik kehidupan akademis maupun kehidupan sehari-hari. 
Kedua hal ini tidak dapat dipisahkan. Seharusnya program dan proses pembelajaran tidak membuat dikotomi antara keduanya. Semua ini menunjukkan bahwa pendidikan adalah upaya membangun budaya suatu masyarakat sehingga tercipta kehidupan modern, maju dan harmoni yang didasari oleh nilai-nilai budaya yang diyakini bersama oleh suatu masyarakat.

\section{Proses Pembudayaan Melalui Pendidikan Formal}

Proses pembudayaan (enkulturasi) adalah upaya membentuk perilaku dan sikap seseorang yang dilandasi oleh ilmu pengetahuan, keterampilan sehingga setiap individu dapat memainkan perannya masing-masing. Dengan demikian, ukuran pembelajaran dalam konsep enlkulturasi adalah perubahan perilaku siswa. Hal ini sejalan dengan empat pilar pendidikan yang dikemukakan oleh UNESCO. Belajar bukan hanya untuk tahu (to know) tetapi juga menggiring siswa untuk dapat mengaplikasikan pengetahuan yang diperoleh secara langsung dalam kehidupan nyata belajar untuk membangun jati diri (to do), dan membentuk sikap hidup dalam kebersamaan yang harmoni (to live together). Untuk itu pembelajaran berlangsung secara konstruktivis (depelopmental) yang didasari oleh pemikiran bahwa setiap individu peserta didik merupakan bibit potensial yang mampu berkembang secara mandiri. Tugas pendidikan adalah memotivasi agar setiap anak mengenali potensinya sedini mungkin dan menyediakan pelayanan yang sesuai dengan potensi yang dimiliki dan mengarahkan pada persiapan yang dihadapi terhadap tantangan ke depan. Pendidikan mengarah pada pembentukan karakter, performa yang konkrit (observable) dan terukur (measurable) yang berkembang dalam tiga ranah kemampuan, yaitu: kognitif, psikomotor, dan afektif. Pengembangan kemampuan pada ketiga ranah tersebut dilihat sebagai satu kesatuan yang saling melengkapi.

Untuk menjamin kekonsistenan antara tujuan pendidikan dengan pembentukan manusia yang berbudaya (enkulturasi), perlu dirancang desain pembelajaran di sekolah yang tidak lepas dari kondisi kehidupan nyata antar dunia pendidikan dan dunia nyata terkait dengan hubungan sinergis. Dengan demikian, antara niali-nilai yang ditanamkan dengan pengetahuan akademis terkait dengan hubungan yang kontinum. Tidak satu pun dari komponen ilmu pengetahuan yang lepas dari nilai dan norma budaya. Wertsch ${ }^{14}$ mengemukakan bahwa dalam mengetahui sesuatu tidak dapat dipisahkan dari budaya yang memediasi dan mentransform tindakan ke pengetahuan. Proses pembelajaran yang demikian dapat digambarkan dalam diagram berikut: 
Sumber

Kebutuhan dan

harapan manusia

dalam kehidupan

saat ini dan masa depan

Analisis kegiatan para spesialis, ahli atau profesional dalam mengembangkan profesionalisme di bidangnya

Analisis struktur materi pelajaran dan pengetahuan kemanusiaan (isi mata pelajaran)
Filter

Perwujudan budaya yang dikembangkan/dibangun

Contoh

Keterangan Diagram:

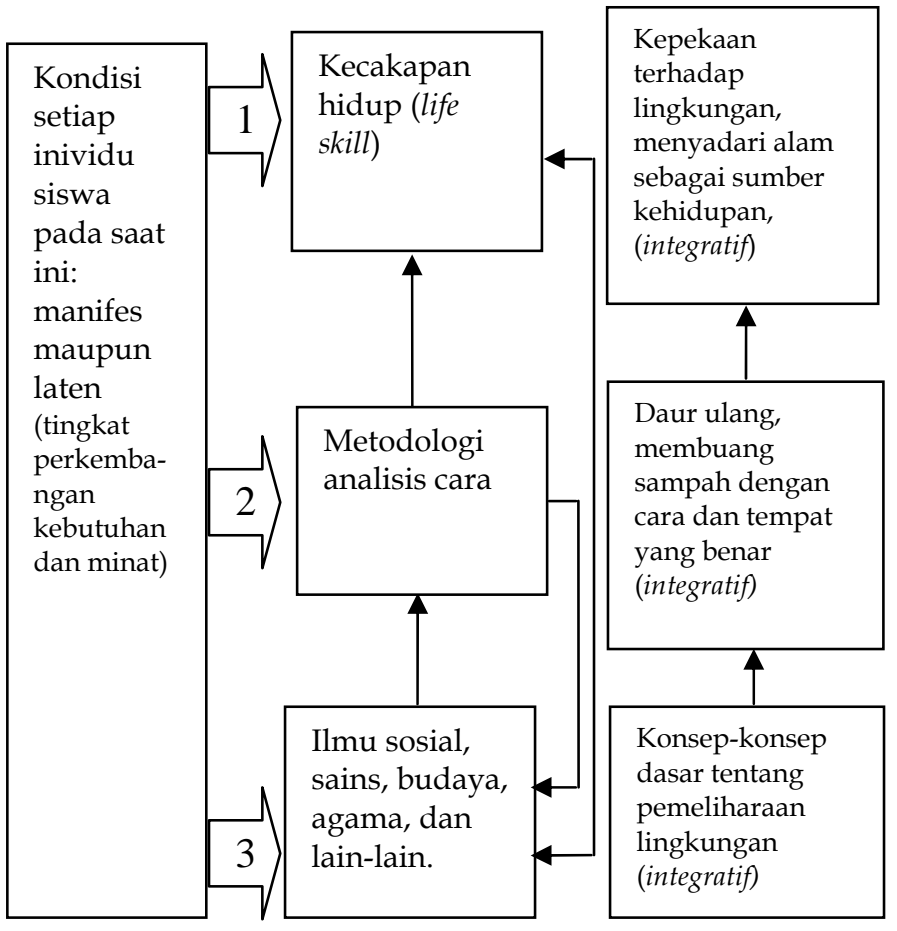

Kecakapan hidup merupakan tujuan dari seluruh mata pelajaran yang mencakup ketiga ranah kemampuan, yaitu kognitif, afektif, dan psikomotor. Pendidikan kecakapan hidup memiliki tiga dimensi tujuan, yaitu: Dimensi pertama, adalah penguasaan dan kepemilikan konsepkonsep dasar keilmuan dengan prinsip-prinsip utamanya. Konsep dasar tersebut dibangun berdasarkan materi esensial yang merupakan bagian integral dari keilmuan (body of knowledge). Konsep dasar ini umumnya bersifat general sehingga dapat digunakan atau terkait dengan disiplin ilmu yang lain (transferable). Konsep dasar harus dikuasai sebagai pondasi untuk menuju kepada kecakapan hidup yang diinginkan.

Dimensi kedua adalah penguasaan atau kepemilikan kecakapan proses atau metode. Kecakapan ini merupakan kecakapan generic yang dipersyaratkan bagi setiap siswa untuk semua jenjang pendidikan yang memungkinkan setiap siswa memiliki kemampuan beradaptasi (adaptability) dan kecakapan menanggulangi (cope ability) serta kecakapan untuk mempelajari (learning to learn). Dengan dimensi ini siswa dibiasakan dan dimotivasi untuk menggunakan pengetahuannya dalam praktik kehidupan di dunia nyata yang didasari oleh kaidah-kaidah pengembang- 
an (proses) keilmuan. Kedua dimensi ini tidak diperoleh secara terpisah ataupun secara berurutan, melainkan diperoleh secara simultan. Karena konsep-konsep dasar (dimensi pertama) tidak akan diperoleh siswa jika dengan hanya menghafal tanpa ada upaya melakukan inquiry melalui dimensi kedua.

Dimensi ketiga adalah kecakapan penerapan konsep dan proses dalam kehidupan sehari-hari sehingga pelajaran berlangsung dengan berwawasan lingkungan (kontekstual). Dengan demikian, siswa akan terbiasa dengan perilaku yang didasari oleh berbagai kecakapan yang diperoleh melalui belajar. Artinya tidak ada jarak antara pengetahuan yang dimiliki dengan perilaku sehari-hari. Proses ini akan membangun perilaku dan sikap manusia sebagai cermin dari sikap dan perilaku mahluk yang berbudaya.

Terkait dengan proses pewarisan budaya, ketiga aspek budaya (universal, nasional, dan lokal) sebagaimana disebutkan pada bagian pendahuluan, didesain dalam suatu kurikulum dengan memberikan porsi yang seimbang di antara ketiga aspek tersebut. Keseimbangan yang dimaksud adalah nilai budaya universal dalam kurikulum yang dirancang yang mengacu pada perkembangan IPTEK, sementara kurikulum nasional mengacu pada nilai-nilai nasional yang terwujud sebagai aplikasi IPTEK dan kehidupan bangsa dan bernegara (wawasan kebangsaan dan nusantara). Budaya lokal menjadi isi dan wahana pembelajaran melalui pemanfaatan lingkungan (sosial, alam dan budaya) sebagai sumber belajar. Ketiga aspek tersebut disusun secara sinergis sehingga muatan ketiga aspek tersebut tidak berpengaruh pada beban belajar siswa.

\section{PENUTUP}

\section{Kesimpulan}

1. Perolehan kebudayaan oleh manusia terjadi melalui proses yang disebut pendidikan. Pendidikan adalah jalur mewariskan dan mewarisi kebudayaan. Akan tetapi pewarisan melulu tidaklah cukup sebagai tujuan pendidikan dengan upaya pendidikan, kita perlu juga membuat anakanak didik itu kreatif dan berinisiatif. Dalam hal ini tidak boleh lepas dari koridor pembudayaan.

2. Pembangunan peningkatan mutu diharapkan dapat meningkatkan efisiensi, efektivitas, dan produktivitas pendidikan. Sedangkan kebijakan pemerataan pendidikan diharapkan dapat memberikan kesempatan yang sama dalam memperoleh pendidikan bagi semua usia sekolah tanpa diskriminatif dan perlakuan yang sama terhadap etnis di Indonesia. 
3. Aspek-aspek pendidikan adalah arah, tujuan atau sasaran yang diperhatikan dan dibina serta dijadikan pedoman dalam pelaksanaan segala aktivitas yang bersifat pendidikan. Aspek-aspek pendidikan adalah pembinaan tingkah laku perbuatan; pendidikan adalah pendidikan diri pribadi; pendidikan diperankan di berbagai pusat lembaga; pendidikan di arahkan kepada keseluruhan aspek kebudayaan dan kepribadian; pendidikan berlangsung sepanjang hidup; pendidikan adalah persiapan penyesuaian yang intellegent terhadap perubahan sosial; pendidik harus mengabdi kepada seluruh massa rakyat; pendidikan harus diarahkan ke pembinaan cita-cita hidup yang luhur; pendidikan jiwa nasionalisme seimbang dengan jiwa internasionalisme; dan pendidikan agama merupakan unsur mutlak dalam pembinaan karakteristik dan bangsa.

4. Pada tingkat individual pendidikan membantu siswa mengembangkan kreativitasnya, kesadaran estetis serta bersosialiasi dengan normanorma, nilai-nilai, dan keyakinan sosial yang baik. Orang yang berpendidikan diharapkan lebih mampu menghargai atau menghormati perbedaan dan pluralitas budaya sehingga memiliki sikap yang lebih terbuka terhadap keanekaragaman budaya.

5. Pendidikan adalah upaya membangun budaya suatu masyarakat sehingga tercipta kehidupan modern, maju, dan harmoni yang didasari oleh nilai-nilai budaya yang diyakini bersama oleh suatu masyarakat.

6. Proses pembudayaan (enkulturasi) adalah upaya membentuk perilaku dan sikap seseorang yang di landasi oleh ilmu pengetahuan, keterampilan sehingga setiap individu dapat memainkan perannya masingmasing. Dengan demikian, ukuran pembelajaran dalam konsep enkulturasi adalah perubahan perilaku siswa tanpa mengabaikan budaya.

\section{Saran}

1. Penentu kebijakan pendidikan khususnya pada pendidikan formal harus mengkaji ulang kurikulum dengan lebih memprioritaskan kekhasan budaya Indonesia dan budaya-budaya lokal.

2. Materi yang diajarkan pada setiap pelajaran kepada siswa seharusnya menitikberatkan pada pengkajian unsur-unsur budaya yang tidak menghilangkan budaya asli bangsa Indonesia. Hal ini diharapkan terjadi penemuan di berbagai bidang pada siswa tersebut. Hal ini berlandaskan bahwa penemuan itu hanya bisa terwujud bilamana berlandaskan pada keaslian dan kekhasan. 


\section{CATATAN AKHIR}

1. Soedijarto, Landasan dan Arah Pendidikan Nasional Kita, Jakarta: Penerbit Buku Kompas, 2008, h. 472.

2. Asian Brain, Pengertian Pendidikan, http://www.slideshare.net, diakses 25 April 2010.

3. Alessandro Duranti, Linguistic Anthropology, Melbourne: Cambridge University Press, 1997, h. 24.

4. Hujair Sanaky A.H., Paradigma Pendidikan Islam, Membangun Masyarakat Madani Indonesia, Yokyakarta: Safiria Insani dan MSI, 2003, h. 146.

5. Ibid.

6. Suyanto, Dinamika Pendidikan Nasional dalam Percaturan dunia Global, Jakarta: PSAP Muhammadiyah, 2006, h. 10-11.

7. Pandapotan Harahap, Pendidian sebagai gejala Kebudayaan http://vandha. wordpress.com., diakses 14 Oktober 2010.

8. Ibid.

9. Nurkolis, Pendidikan sebagai Investasi Jangka Panjang, http://researchengines. com , diakses 6 November 2008.

10. Conny Semiawan, "Kebijakan Pendidikan Dasar danMenengah", dalam Tilaar, Pendidikan untuk Masrakat Indonesia Baru, Jakarta: PT Grasindo, 2002, h. 191.

11. Yin Cheong Cheng, School Effectiveness and Schooll-Based Management: A Mechanism for Development, Washington: The Palmer Press, 1996, h. 7.

12. Bertha Perez, ed., Sociocultural Contexts of Language and Literacy, London: Lawrence Erlbaum Associates, 2004, h. 4.

13. Zulfikri Anas, Pendidikan dalam Budaya, http://fikrieanas.wordpress.com, diakses 3 Oktober 2010.

14. Bertha Perez, ed., op. cit.

\section{DAFTAR PUSTAKA}

Anas, Zulfikri, Pendidikan dalam Budaya, http:// fikrieanas.wordpress.com.

Brain, Asian, Pengertian Pendidikan, http://www.slideshare.net.

Cheng, Yin Cheong, School Effectiveness and Schooll-Based Management: A Mechanism for Development, Washington, The Palmer Press, 1996.

Duranti, Alessandro, Linguistic Anthropology, Melbourne, Cambridge University Press, 1997.

Harahap, Pandapotan, Pendidian sebagai gejala Kebudayaan http://vandha. wordpress.com.

Nurkolis, Pendidikan sebagai Investasi Jangka Panjang, http:// researchengines.com.

Perez, Bertha, ed., Sociocultural Contexts of Language and Literacy, London, Lawrence Erlbaum Associates, 2004.

Sanaky, Hujair, A.H., Paradigma Pendidikan Islam, Memangun Masyarakata Madani Indonesia, Yokyakarta, Safiria Insani dan MSI, 2003.

Semiawan, Conny, "Kebijakan Pendidikan Dasar dan Menengah," dalam Tilaar. Pendidikan untuk Masrakat Indonesia Baru, Jakarta: PT Grasindo, 2002. 
Soedijarto, Landasan dan Arah Pendidikan Nasional Kita, Jakarta, Penerbit Buku Kompas, 2008.

Suyanto, Dinamika Pendidikan Nasional dalam Percaturan Dunia Global, Jakarta, PSAP, Muhammadiyah, 2006. 